\title{
Sir John Oldcastle
}

SINCE the early days of the English Reformation Sir John $S$ Oldcestle has held a high place in the traditions of his country. Two of the chief adrocates of protestantism, ening edifcation in the history of their Lollard predecessors, published accounts of his suffarings; and his renown, proclaimed by Tyndale's work,' and doubtless incresed by the issue of Bale's Brefe Chronycle, grew higher and higher till he came to be regarded as a national bero. Early in the reign of Elizabeth, however, Fore had to defend his enlogy of Oldcastle against the criticism of a Roman catholio historian; and a generation or so later the Lollard adrocate broke a lance with the dramatists, whose traditions made Oldcastle s roystering buffoon. The sympathies of the escendant party were on Fore's side; his reply succeded in silencing his opponent, and Shakespeare was driven to change the surname of a tamous character from Oldcastle to Falstaff.' Oldcastle's fome has been kept alive down to modern times by fresh editions of old works and the publication of ner ones. He has been associated with Wycliffe, Has, and Latimer as one of the heroes of the Reformation," and with Wat Tyler and John Ball as a "popular leader' of the middle ages;' and in the hands of one writer the Lifo and Times of Lord Cobhan have boen made to fll two sub.

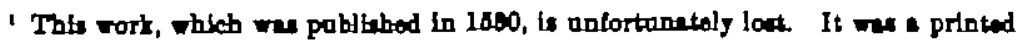

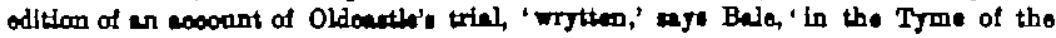

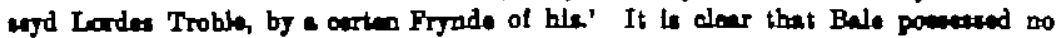
copy of Tyndeb's cocoont, and hil mention of it topilos thet it wes already rery rere (Brefo Chrompole, ed 1799, p. 4). This maj perhepe be cooconted for by the feat that the book wa oondermod by Arohblehop Wertem in 1581 (Latters and Papers of How $V I I$, r. 780 ).

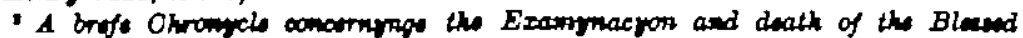

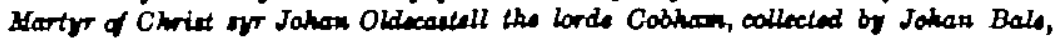
1at ed. Iondon, 164t. A moond adtiton appered in 1600. It wes printed by William Bleckboume, a nonjuring bichop, in 1729, and th also to be fond in the Harkan

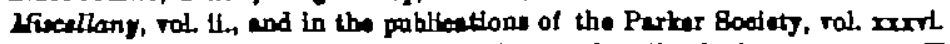

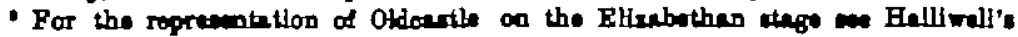

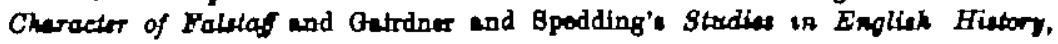
pp. 65 E.

IV. Gllph, Ltow of the Reformors, 1et ed. 1705.

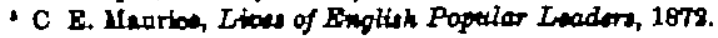


stantial volumes." Numeroue other historiang have dealt with Oldcastle's life; eighteenth-century torie sought in his career ergumente against the whigs; ${ }^{7}$ and more recently Tennyson put one of his ballads into the mouth of Oldcastle, who is made to soliloquise at length on hie misfortanes."

Thus the literatare on Oldcastle is remarkable for both bulk and variety; and were it all based on sound methods his oheracter would by this time be clearly established. But, unfortunately, the main source for almost every account is the chronicle of Bale, whose facts are often drawn from secondhand anthorities, and often, it is to be feared, from no anthorities at all. It is, consequently, no wonder that recent research has added much to our knowledge of the Lollard leader, while at the same time diacrediting many supposed facte. The result is in the most recent article on Oldcastle,' where the 'good Lord Cobham' of previous priters is scarcely recognissble, and the hero is depicted as a commonplace knight whose renown is merely dae to his connexion with an unpopular

Sir John Oldeastle came of a Herefordshire family of no great account, whose headquarters were at the village of Almeley, near the Wye, in the extreme west of the county. The origin of his name is obscare. It cannot heve been derived from the reridence of the family in Almeley Castlo $a$ building of $\operatorname{som} \theta$ defensive strength, situated on a mound close to the village church. There is no mention of such a fortiflation either in Domesday or the early lists of border strongholds; so that the castle, if already built, could hardly hare been considered ' ald ' in the days of the first Oldcastle of whom we heve any record-- the Lollard's greatgrandfather Peter, who murt have flourished aarly in the fourteenth century. It seems, however, that a Roman camp was at one time established on the aite occupied by the medieval etronghold; so that the neme Old Castle may have been first applied to its remains, then to the family who lived on the site, then to the hamlet which grew ap round their dwelling, and finally to the later fortification itself." Since the time of Peter the Oldcastles had risen in importance. Sir John's grandfather, also called John, twice, in 1868 and 1972, represented Herefordahire in parliament. ${ }^{11}$ His uncle, Thomas, was still more prominent. He was at the

- T. Gaspay, Lifo and Tirras of Lord Cobhane, 1848.

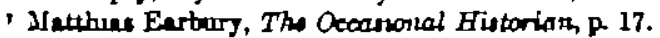

- Balladr and oxher Pooras, p. 112.

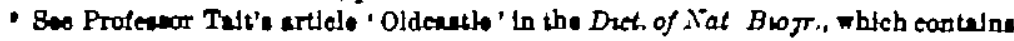

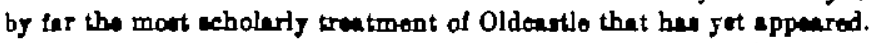

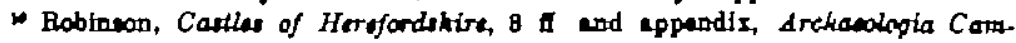

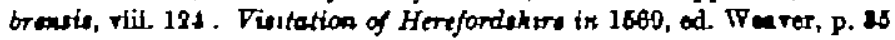

"Rox. Parh i 179, 18 . 
parliaments of 1390 and 1899 , held the office of sheriff in 1886 and again five years later, and was escheator for Gloucenter, Hereford, end the adjacent march in 1989.'? The Lollard's father, Richard Oldcastle, was the first of the family to be mighted. ${ }^{18}$ Nevertheless the family was not well off in material resources, having ferr, if any, possessions outside the manor of Almeley. ${ }^{14}$

The date of Sir John's birth is unknown. A late tradition "s puts it at 1360 and an untrustworthy contemporary at $1878 ;^{18}$ it was probably nearer the latter date. His name frst occurs in a ples roll of 1400 , where he appears as plaintiff in a suit against the prior of Wormesley concerning the adrowson of Almeley Church. His grandfather had presented to the living in 1368, but eince that time either be or his воn Richard had granted the advowson to Wormesley Priory. When John Oldcastle's presentee resigned, about the close of the century, the grandeon strove to prevent the priory from exercising its right; but we are not told how the dispute was settled. ${ }^{17}$ Oldcestle is nert found in Scotland, on the occesion of Henry IV's futile expedition in the autumn of 1400 , as a knight in the retinue of Lord Grey of Codnor. During the operations he was sent on a mission to the king, and thenceforth was continually receiving employment in the royal serrice. ${ }^{18}$ In the following years Oldcastle hed much to do with the affairs of Wales and the southern march, which were disturbed by Glendower's rising. In Alay 1401 eeveral Herefordshire gentlemen, of whom Oldcastle was one, were commissioned to raise the pase comitatus against certain rebels who had committed namerons misdeeds near Abergavenny." In the autumn he was captain of

1 Rot ParL L 287, 244; Lists of Sherhfs, p. 00; Foedera, ril, 646.

t Do Beneo roll, Eerter 1 Hen. IV, m. 199; Robinmon, epp; Tearer's Viritation.

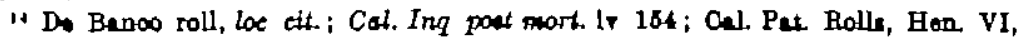
1. 647. It it not cortein whothor Blr John's enceston held the lands outalde the manor of Almoloy mentioned in the reoords; the entry in tho patont roll mekes it poatble that he wes the Arat of the temlly to pousest them.

is Followed by Geppey, G. E. C., Complete Peerage, rL 110 ; Arch Cambr, rlii. 121.

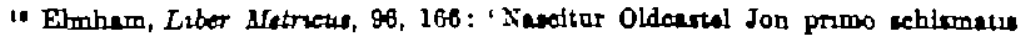
ando' From thl, Elmbem ergoes thet Oldoentle was the becrt of Rer. Illi 11, 18 He takes the numanal lettars of the tro ronds Jon Otdcastel : $I+L+D+C+L=701$. This look mpromleins; but if Oldeastle was born in 1378 he was thirty.fire In the

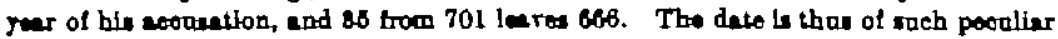
cooreniemoe to Elmhem that one is diepoed to doubt its authentlelty BIoreorer, as

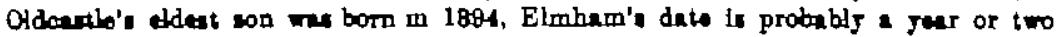
ont.

17 Do Beneo roll, Eester 1 Hon. IV, m. 199 ; Rabinton, Ciustlas, p. 4. After both parties hed presented their ploas the case was adformed till the following Trinty; bat in the roll for thet term there wems to be no mention of it.

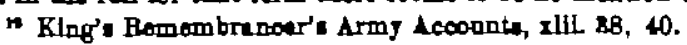

- Cal. Pat. Rolls, Bon. IV, i. 61 . 
Builth Castle, so and was soon afterwards set over the important stronghold of Kidwelly." In September 1408 he was on a commission emporered to pardon rebels who submitted in an extensive district of the madern Brecknockshire," and a year later wa made superintendent of the castles of Hay and Builth." Oldcastle Wes also one of the commiscioners appointed in October 1404 to repress trade between lukewarm loyalists and the Welsh rebels." But Sir John did not devoto all his energy to military mattere. He was returned as knight of the shire for Herefordshire in the parliament which met in Jannary 1404," and was thas present at an important and exciting session. In $140 \theta$ he wos a justice of the peace," while two years later he followed in his uncle's footsteps and became sheriff, ${ }^{27}$ January 1407 found him at Carmarthen, on businese connected with the Welah revolt. Daring the following sammer he accompanied the main army against Glendower, essisted in the operations against Aberystryth, and was one of the witneseses to the agreement made on 12 Sept. between besiegers and besieged."

The next year proved the turning point in Oldcastle's life. Bir John had been already twice a husband. His first wife, whom he married before 1994, came of a Welsh family-Katherine, danghter of Richard ap Yevan. By her he hed one son, John. Of his second wife nothing - not even her name-is known, eave that she bore him another son and three danghters." Oldesatle now married, before the middle of Jone 1408, Joan Cobham," a lady who had already been thrice wedded, and had had three children, though only one, Jokn, danghter of Bir Reginald Braybrooke, had gurvived. The death of her third husbend in the entumn of 1407 was elosely followed by that of her grandfather, the famous John, third Lord Cobham, who closed a long and gtorious career on $10 \mathrm{Jan} .1408$. He left no heirs male; his only deaghter was long eince dead; and his recently widowed granddenghter came into all his possessionn.

- Procudinge of the Provy Coxroth, 1. 174.

- Fondera, vilt, 881.

I Toid. ti 68

w Wyble, if 8 .

n Proc. of the Privy Concretil, L 98.

- Rot. Parh 1. 205.

- Plot. Pat. 7 Hen. IV, p. 1, m. 28 d. In the provloun autamn ho hed ben ano of the oommladoners appotnted to delliver Hereford Geol : ibid. m. $28 \mathrm{~d}$

"Liste of Sherifies p. 60. Hid term of aflow lested trom 6 Nor 1406 to 23 Nor. 1407.

- Rot. Pat. 0 Hen. IV, m. 6.

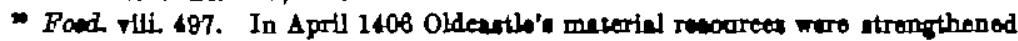
by crown grints of $10 \%$ and 10 merke par annum, to bo drawn rewpeotivoly trom the revenues of the duchy of Laneater and the lordahip of Monmouth: Dac. Lame.

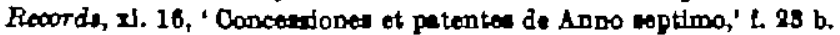

- Rot. Clento Bon. V, m. 14 ; G E. O., Complete Perrage, ri. 119

"Ibid.

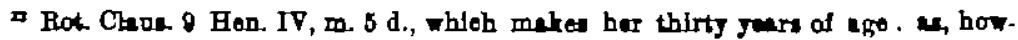
orer, the wh already mertied In Nov. 1880 (Rot. Porl. v. 401), this mast be inoorrect. Joen we the deaghter of Bir John Delapole by a deaghter of Joho Cobhem, aleo alled Jonr. 
Joan at once sought $n$ ner hasbend to aseist her in managing her property, and her choice fell upon Oldcastle."

The marriage meant a great rise in the fortanes of Sir John. Hitherto he had been merely a Herefordahire knight, of some consideration in his own circle, and no more. Now, through his Fife, he edded to his scanty estates the broad domains of one of the most notable families of Kent. For two hundred years the fortunes of the Cobhems had been eteadily rieing; and Joen was able to bring to her husband six manors and the revenues of the hundred of Shamley, in Kent, a manor in Norfolk, two in Northamptonshire, and a like number in Wilts, with a honse known as Cobham's Inn, in the parish of St. Iunstan-in-the-Esat, London, ${ }^{\text {H not to speal }}$ of Cooling Cartle, which the energy and public spirit of Josn's urandfather had made one of the most formidable atrongholds in the country. ${ }^{2}$ It may be notod that Lord Grey of Codnor, who had been Olderatle's captain in 8 cotlend, hell the manors of Hoo and Halstow, bordering on the Cobham lands in Eent : " possibly through him Bir John became aoquainted with his wife.

Though the centre of Oldcastle's interests was now far away from Wales, his connerion with the march was not all at once broken off. During 1409 he, together with others, was grented the prardship of the lordahip of Dynas, an estate not many miles distant from Almeley." But his time was soon engrossed by more important duties. In the sutumn of 1409 the king found it neceseary to call a parliament- the firet since Oldcastle's marriageand Sir John was summoned to attend as a member of the upper house. ${ }^{28}$ Henceforward till his eccusation in 1413 no parliament met whthout his receiving 6 eimilar summons. It is dispoted whether Henry intended to found a new berony in Oldcastle's Invour, or summoned Oldcastle merely in right of his wife." The vrits alway日 refer to him as 'John Oldcastle chivaler,' as though his connerion with the Cobhame had nothing to do with the summons. But two other members of the house of lords-one contemporaneous with Oldeastle, the other nearly so- are regarded ly Dugdale as posessing their seats ure uxorne, though they are summoned ander their orn names, with no mention of the family Into which they had married. ${ }^{*}$ Little eignificsnce, however, can

- Comp. Parrage, 11 817; Collectarea Topographica et Gomealogica, vil. 829, 888. For an soosont of Jonn's baubends-81r Robent Homonhelo, Bir Hegineld Braybroake,

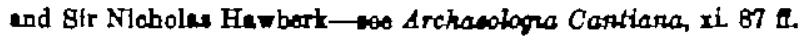

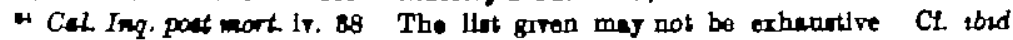
1H. 81, 179, 815; iv. 155

- Arch. Oth il 128 it

ir Cal. Rat. Chart. p. 069.

- G.E.C., Completo Peorage, IL 119 ; Dugdelo, Bummortut. Parl.

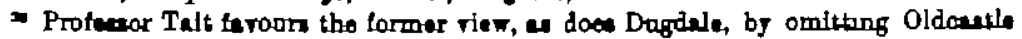
from hus lint of those summonod iwro wrorit G E C. fnellnes to the other theory.

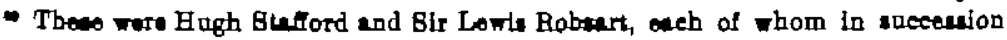


be attached to the fact that the peerage was afterwards continued In the line of Cobhsm, not of Oldcastle; for, since condemnation for treason forfeited all rights of peerage, Oldcastle's heir had no more claim to a sammons to parliament than any other gentleman in Englend. Aloreover after Oldcestie's condemnation no representative of the Cobhams appeared in parliament for over thirty jears, though either Joan's fifth hasband or her son-in-law might properly have been summoned ure uxoris. Consequently the action of Henry VI in summoning Edward Broke as Lord Cobham practically amounted to the creation of a ner barony.

It 18, perhaps, imposaible to arrive at any definite conclunon on the matter. The ideas concerning the qualification for a seat among the lords temporal were much less fixed in the early flfteenth centary then they afterwards becsme, and the practice with regard to the issue of summonses was probably eomewhat loose. On John Cobham's death it must have been thought inadvisable that the great Cobham interest ahould be anrepresented in parliament; while, doubtless, Oldcastle's previous serrices were not left out of account. Although Oldcastle's right to a summons may not have been derived from his wife in theors, it is probable that this was partly the case as a matter of fact. If he had not married into a great family Oldcastle would acarcely hare receired his summons : with the example of Richard II before his eje Henry would never heve ventared to confer sach an honour on a knight of Oldesstle's standing, however great his personal regard for him. Bat, on the other hand, the fact that Henry V never summoned Joan's fifth husbend would seem to indicate that marriage into the Cobham family was not in itself sufficient, bat that proved ability was also requisite.

Although the writs had been issued on 26 Oct. 1409 it was late in the following January before parliament actually assembled. Sir John made ase of the interval to cross the Channel and take part in a tournsment at Lille. Three Englishmen were opposed to thre Frenchmen ${ }^{41}$ and Oldcastle duly fought his opponent; but how the contest went we are not told. Neither combatant can hare been much hart, for the same night they both supped with the count of Neverb, who was acting as master of the ceremonies. After three days of great magnificenoe and heary expense the tilting came to an end.

Parliament met at Westminster on $27 \mathrm{Jan}$. The session was a long one, lasting till late in April, with an Easter recess of

we the husband of Ellaboth, denghtor and hoiren of Bartholomow, Lord Bourchtor.

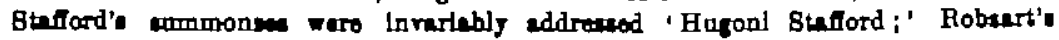
'Lodovioo Robesuert Chl'r.'

"The attompte of our Bargundian anthortty to roproduce the English nemes are

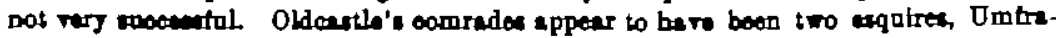




three weeks. Though everything soems to have passed quietly, this parliament aftermards acquired a certain notoriety through the apocryphal stories of chroniclere concerning the doings of the lower house. Walsingham tells as thet the milites parliamentales (cel, ut dicantu verius, satellites Pilatales), eagerly desiring the spoliation of the charch of God, presented to the king a bill, in which they sought to demonstrate that confiscation of the temporalities of the clergy would enable the king to provide for fifteen new earls, 1,500 knights, and 6,200 esquires, and to found a hundred almshouses. ${ }^{22}$ a manuscript of Titas Livius's Lyfe of Henry $V$ gives us further details as to this scheme. ${ }^{\text {ts }}$ The flgures here to be taken from a tract containing a list of the errors of John Porvey, who some years belore had adrocated conflscation on the asme grounds." Walsingham goes on to relate that when the knights were asked whence all the neceseary money could be derived they broke down atterly, and thereapon the king forbede them to mention the mstter again. Foiled in this plan, the coetus execrabilis petitioned that clerks convicted of secular offences should thenceforth be handed over to the prisons of the king and the temporal lords; and when another unfavourable answer was receired they brought ap a further petition, that the 'Statatum de haeretico comburendo ' might be modifled. But they were told that any alteration would be in the direction of greater strictness. After this rebuff the attack toems to have been abandoned.

Later chroniclers and higtorians have largely accepted this story, and have laid specisl stress on the statistics of the knights with reference to church property. Mr. Wylie himself thinks that some sweeping proposal of confiseation was brought forward, and regards Oldeatle as the ringleader in the whole affair. Bat a comparison between the chronicle and the offcial records leaves little room for donbt that Walsinghem has been gailty of grose exaggeration, if not of sheer invention. There is, indeed, a stratum of trath onderlying his story. It is certain thet the knightly element in the lower house was decidedly enti-acclesiastical in temper, and that the commons petitioned for a modification of the 'Statutum de hasetico,' of such a nature as virtually to abrogato it. th The members of the lower house also represented that under

a Woldngham, Brith Argi i. 2888.

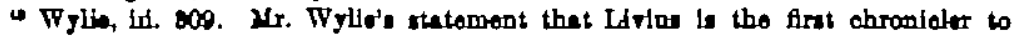



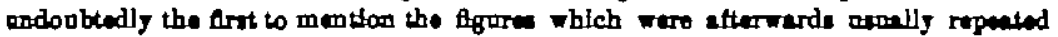

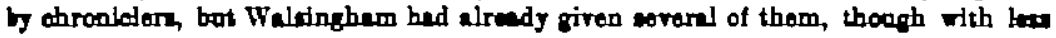
inteil.

4 The tract anems to beve bees compllod by one Rieherd Largahem, a Oermelite




Factetilh bat tbe difformosis are anfmportant.

" Rot. Parl iil. 697. One of the ohief points of the statute of 1401 we the 
colour of acting pro salute anmarm the ecclesiastical officials were ertending their jurisdiction to matters cognisable at common law; the king was therefore reqnested to frame a atatute to deal with these encroachments, and to enact that all contraveners thereof shonld suffer imprisonment, pay a fine to the king, and indemnify the injured party. ${ }^{\text {th }}$ ds legislation on the sabject elready existed, Henry refued to take further measures; but the incident seoms to have alarmed the charchmen, and by the time news about parliament reached the St. Albans scriptoriam a comparatively modest request had grown into a propasal that all criminous clerks should in fature andergo panishment at the hands of the secular power. While there is no evidence of the introduction of such a sweeping scheme of confiscation as that mentioned by Walsingham, a petition is enrolled in which the commons begged that half the revenues of absentee incambents and of livings which had been appropriated under false pretencer should be seized into the king's hand, on the ground that the country was impoverished through the continual rars."7 Walsinghem's account gains little real confirmation from the work of Titas Livius, which was written later than 1487 and in which the passage in question is poseibly interpolated. ${ }^{13}$

That Oldcastle had already adopted Lollard views is made clear by an incident which occurred during the Easter recess. It is indeed likely that he had long tavoured the new doctrines. On the assamption that he was born abont 1375 he must have lived in an atmosphere of Wyclifite teaching from his youth op. By 1890 the unstable fanatic William Swinderby and the mystical layman Walter Brate were working in Herefordshire and giving Bishop Trevenant no emall trouble." Richard Wiche too, who seems to have been intimete prith Oldcastle, wa originally a priest of the diocese of Hereford, though his activity afterwards extended over many parts. ${ }^{* 0}$ Nor were the preachers the only source whence Oldcastle may have 'drank the gall of heresy.' The west country knghts were not disinclined to favour the reformerg. Bir John Clanvore, of Cusop Castle, not many miles from Almeley, is mentioned 28 one of the early patrons of Lollardy," and later events auggest that the Greyndors, who had much property in the pest, were on the same side."s Perhaps it

power it gave to the clargy of meiting erreste on thair own Initintive. In their petition tbe commons asked thet in fotore these shortd be mede only by the oflows of the crown.

- Rot. Parl il. 6t5. " Ioid.

- It dow nos cecor in the menawerlpt ased by Hearme in propering his printed odition; seo Wylit, iH. 810, n.

- For 8winderby and Bruto neo Foxo (ad. Cettley), hi. 111, 181, 196.

- WyHe, Hil 868 ; Eagl Huth Reo. v. $\$ 80$ L; Davon, Iance, p. 859.



- Elmhem, Lib. Latr. p. 148, Ceporare, De allustr. Honticio, p. 121. 
was from the preachers that Oldcastle derived his enthusiasm for the new ideas, while the restraining influence of the knights kept him from fanaticiom and tanght him that even a Lollard might serve both his God and his ling.

But until 1410 there is no anthentic indication that Oldcastle Fas anything but a datifol son of the charch." During the early months of that year the real of the orthodor bornt strongty. Niacb excitement had been csased by Arundel's conflict with the unirersity of Orford, where a recrudescence of Wyclimte teaching had given canse for alarm. In 1409 \& provincial constitution had placed new weapons in the hands of the clergy, 4 and soon afterFards John Badby, the poor tailor of Evesham, was put to death. 0n 3 April 1410 Arundel eent a letter to the dean of Rochester, in which he stated that one John, feigning himself a chaplain and drelling with Sir John Oldcastle, had for some time past been preaching Lollerdy in the churches of Hoo, Helator, and Cooling, especially the last; the dean was therefore to proclaim an interdict in these places, and to provide for the citation of the chaplain, who was in hiding." Though Oldeastle is nowhere accused of instigating the chaplain's misdeeds it is likely that Arandel meant his action to be a hint to the protector quite a much as a blow at the protected. A timely accident, however, averted the threatened trouble. It so happened that a marriage between Sir John's stepdanghter, Joan Braybrooke, and the heir of Sir Thomas Broke, a Bomerset knight, was to take place in Cooling Church early in April. Joan's mother and Bir Thomes, whose orthodory was above sus. picion, were neturally anxious for the speedy removal of the interdict, and the archbishop suspended 2ta operation for three days, in order that the wedding might be celebrated, and some time later relared it altogether."T The offending preacher was apparently forgotten. As for his patron, far from being moved by Arundel's hint, he identified himself more and more with the Lollard cease, and in the following summer we find him connected with the Bohemian Wyclifftes.

The researches of Dr. Loserth" hare made it clear that

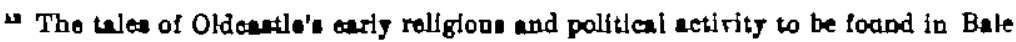
end serernal heter writers are besed aither on a fallare to distingulal betroen the busband ad grandiether of Joen Cobbem, or alen on conjecture or invention

st Wulkinh Conctina, lit 814 It.

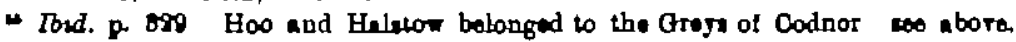
p. 488.

- Colloctarea Topographrca of Genealogica, Fl. 888. There is oridence that the

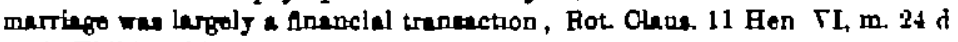

- Willon iil $000 \mathrm{t}$.

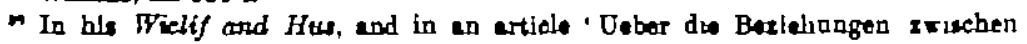
ongliecher and bahmiechen Wioliaten' in the Mutheilunger des Instituts far

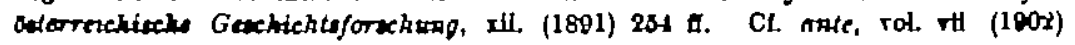
pp. 306 II. 
ever since the marriage of Richard II to Anne of Luxemburg intercourse between England and Bohemia had been continuous and extensive. The most important result had been the introdaction of Wycliffte viers among the Crechs. B5 1410 heresy had beoome so popular among all classes that the church mas striving to restore orthodoxy by force, and it was with this end in new that the archbishop of Prague, about the middle of July, had numerous works of Wrcliffe burnt. The wrath of the people at his action found erpression in satirical ballads and even in open disorder. The reform party in the unversity, too, strore to retaluate on the archbishop by organising a series of pablic lectares, at which the condemned books Fere defended by prominent theologians. Newe of all this was eoon carried to Englend. On 8 Sept. two congratulatory letters were sent in reply-one to Hus from Richard IViche, the other to Wok of Waldstein from Sir John Oldcastle. ${ }^{*}$ Both are in Latin, and while Wiche probably wrote in person the form of Oldcastle's letter is evidently dae to a clerk. The general tenour of the communication 18 , doubtless, a reflexion of Bir John's opinione, but the details of it must not be pressed too far as proofs of his knowledge or literary skill. Wok of W'aldstein to whom the letter was sent was a member of the Bohemian noljility and an enthugiastic Hussite. His chief exploits belong to a later date; he was the ringleader at the burning of the papal bulls in 1412 , and one of the nobles who protested against the treatment of Hus at Constance and lound themselves to maintain the freodom of the Gospel. Zdislaw of Zwierteticz, to whom Oldcastle's letter was to be taken in the event of Wok's absence, Tas likerrise a strong upholder of Wycliffite riers. He had quite recently graduated at Pragne, and had been rery prominent in the attachs on the archbishop daring the summer of 1410 , having defended IVycliffe's treatise 'De Lniverealibas' in the Carolinum on $6 \mathrm{Aug}$. Shortly before he had been excommunicated. That Oldcastle should be in communication with tro of the protagonists of the reform party in Bohemis shorr that for some time past he mast have been recognised as a leader of English Lollardy. Perhaps he had met the tro Boheniens in England, though there is nothing in the letter to suggest this.

The letter begins with congratalations on the recent achierements of the Bohemians, but the greater part of it is taken ap with exhortations to perseverance and endurance. The quotations from Isidore and Chrysostom are doubtless the work of the scribe, bat Oldcastle himself may be responsible for the numerous references to Scripture. The letter shorrs clearly that he accepted fally the leading principles of Lollardy. He lays particular stress on

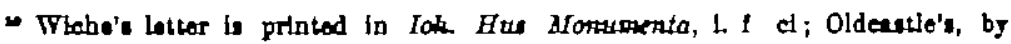

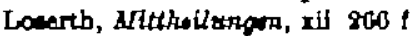


the daty of priests to preach the word of God and suppress nothing; any one who strives to prevent their doing so is none other than antichrist. So anrious is he that his Bohemian brethren shall realise that he means to stand by his viers that he affres his seal to the end of the letter, quol nunquam apponimus ad litteram que deberet in pasterum equeri." To the Bohemiens, therefore, Oldcastle's letter must have seemed a manifesto of the policy of the leader of English Lollardy.

We know from a later letter of Oldcastle's 's that the correspondence between the two countries was kept up, and that Hus himself wrote to his English supporter. According to Thomes Netter of Walden, whose statement is unsupported by other eridence, Sir John, at the request of Has, sent copies of Wycliffe's works to Bohemia. Walden was mistaken if he believed-as his language seems to imply-that this was the means whereby the Czech flrst became acquain ted with Wycliffe's writings. Wycliffe's phulosophical works, es Dr. Loserth has shown, were knomn in Prague long before the close of the fourteenth century, and in 1899 Jerome of Prague, returning home from a visit to England, took with him the Trialogus and Dialogus, and so introduced the Englishman's theology to his countrymen. Before Hus obtained any great notoriety Wycliffite literature was plentiful in Prague.s It is possible, indeed, that Hus at some time asked Oldcastle to add to his library of Wycliffe's worke. But it is equally likely that the story is one of the numerous legends invented to account for the wide dissemination of heterodor views among the Crechs. The Bohemians themselves soon forgot how the Lollard teaching came into their midst, and Walden, writing as he did when both Oldcastle and Hus had been in their graves for some years, would

- The menneript as printed by Dr. Lowerth hat ' ovesert.'

a To King Teneeslen. The letter is printed by Dr Lowerth and ato by Mr Wrilie,

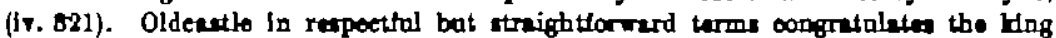
on the empport be he getren to the reformers, and argee him to perworere in his coorw. The lotter in deted 'London, 7 Sopt.' bat the jear to not giren. Dr. Loworth

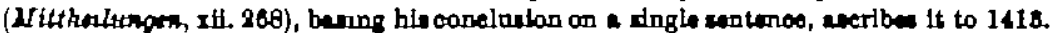
The affoinl report of Oldenctlo's triel, howover, make it dmost cartein that he ne at Cooling on 7 Soph of thet sear. The lendatory tone of the latter roold

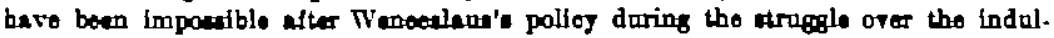
gonea which disureted Pragae in 1412, and atter he hed ritually drivon Has into

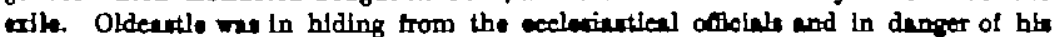
Hife, bat be nowhere hiote at bis sitnation, bath on the contrary, decleres htmealf rendy to wre Wencealen es the latter may thlnk ft. To me 1411 cooms a much more litehy date; tor in the summer of thet year Ofdeacth may well have thought that Wencealens was heart and woul with the rotormers. The verg relerenes relled on by Dr. Laverth soitu 1411 quite as woll a 1418. CL. Palecty, Gaxch Bahrs. Hif. 258,281 II.

- Talden, Dactrmate, 15b. II c. 70.

a Losertb, vittheilurgen, xil 258, Wiclyf and Hur pp. 74 If 84 ti.

4 Itotd. p. $71 \mathrm{fl}$. 
naturally be led to connect the two men with the sowing of the pertiferous ed.

The letters show that Oldcastle's opinions remained unchanged daring the nest year or two. But he seems to have kept his Lollard proclivities in the background, and continued to serve and flght for his king as before. In September 1411 he was on a commission to exmine the walls and bridges along the reaches of the Thames between Northfleet and Greenwich; ${ }^{\text {st }}$ and immediately afterwards he was associated with the earl of Arundel and Robert and Gilbert Umfraville in the command of the force which was about to be sent to France for the succour of the Bargundian party. The dake of Burgundy's application for help was not favourably received by the kmg, and the despatch of the force is and to have been an irregular proceeding on the part of the prince of Wales. The enterprise $\pi$ ras, horrever, successful. The aseistance of the English enabled the Burgundians to occups Paris and defeat their opponents at 8t. Clood, and turned the acale of war for that year in their farour. The Englishmen greatly distinguished themselves, but of Oldcastle's personal achievement we hear nothing. It is clear, however, that Sir John was on good terms with young Henry, and was regarded by him es one of his most trustrorthy oldiers. About the end of the year the whole force returned to Englend. ${ }^{\circ}$

On the death of Henry IV, in March 1418, it might have been thought that his son's accession would tend towards Oldcastle's further advancement; bat the Lencastrian power rested to no small extent on ecclesiastical support, and the zeal of the church had lately been fanned afresb by the council held at Rome in the early month of 1418, which had condemned many of Wycliffe's pritings as unfit to be read or possessed by good Christians, and as deserving to be barnt.

Before the death of the king conrocation had met, the first session hering been held on 6 March. Fore, for once independent of Bale, saye that the purpose of the summoning of this assembly was the repression of the Lollards, end in particular of Oldcastle, ' as recordeth the chronicle of St. Albans.' There were, indeed, numerous reasons for holding a convocation. The king had directed it ; there ras a subeidy to be grented ; the question of the sehism had to be discused. If there bed been no heresy in England, the conrocation would probably have met. But it is likely enough

- Wylio, lil 298.

- Gath Howr. V, p. 280, Ottorbourna, p. 288, Wullingham, ii. 286, Gregorg, Chroricla, in Hutorical Colletions of a Citiven of Lardon (ad J. Gelrdnar), p. 106; Theree Fiftunth-Contury Chronicle (od. Getrdner), p. 68, Chron. Lond. (od. Nicolas), $p$ $\theta 8$

- For en recount of the expedition wylne, iv. 87 ff.; Bemeng, Lancaster and York, 1 l80 
that, when Henry IV died, Arundel asw in the change of ruler a good opportanity for gaining the energetic support of the acular arm against heretics. Of recent years Henry IV had been loth to act vigorously. But the new king would be enger for the support of the charch, and willing to pay a high price for it. Even his friend Oldcastle might be won from him by a little dexterous diplomacy. The case of Oldcastle was brought onder Arandel's notice on the first day of convocation. In the afternoon the archbishop's registrar, who hed just completed his eramination of the credentials of the proctors, was informed that there was present in the charch a cheplain strongly suspected of heresy. Bummoned before the registrar, the chaplain stated that his name was John Lay, and that he came trom Nottingham; he had been two days in London, and had that morning celebrated mase before the 'lord Cobham.' On this the registrar demanded his certifleste of ordination and his licence to celebrate; but Lay replied that he had brought neither with him. He was therefore arorn to attend before the primate on the following Saturday, to show bis credentials and do further what might be required. But we hear nothing more about him; probably he failed to appear at the time appointed." It rould be interesting to know whether this John Lay was the priest whose doings had led to the interdict on Cooling Charch in 1410.

Before any real work could be done stress of perliamentary business compelled Arandel to suspend the sittings of the clerical 2asembly. Then came the death of the king, and afterwards parliament took ap more time. Little bueinese could be done till 6 June, and the eesaions hed to be held in Lambeth Charch instead of at St. Paul's. The first occurrence of importance was the presentstion of the report of a commission appointed in the previous year to examine Wycliffe's works. The members of the commission now presented 267 extracte for condemnation, and suggested that after conrocation had dealt with them they should be eubmitted to the pope. ${ }^{\text {TO }}$ Their proposal was accepted. The articles were condemned forthrith and then sent on to Rome. The archbishop accompanied the extracts with a letter, in which he asked for the confirmation of the eentence of convocation and for the condemnation of Wycliffe and his adinerents. He also prayed that the reformer's bones might be exhamed and thrown on a dunghill. ${ }^{n}$ The tractates containing the objectionable conclusions rere efterwards burnt at Paul's Cross. ${ }^{\text {"x }}$

- Willong lli. 280.

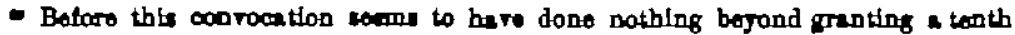
to tho Hng during Jey (Reg. Arundel, it. 1. 27). Willing hes not tranecribed the regtater vary falthfolly in the Concille. From the tert there printed it woald eppour

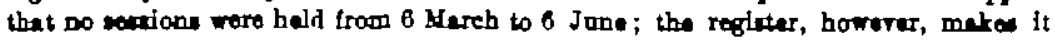
dear thet womothing, thoogh rery hittle, wes ettamptod.

- Wilkine, il. 859 
Convocation continued to eit till 26 Jane. Daring ito closing days Arandel was absent and the bishop of London presided. IInch discusaion took place concerning the reform of the church. The petitions of the clergy on this point suggest that the archbishop had not, in their opinion, been strict enough. They pray for the stricter enforcement of varions provincial constitations, most of them originally laid down by Otto or Ottobon, and providing for the orderly life of the clergy. Convocation also begged that the new enectments of 1409 might be amended, with a view to increasing their efflcacy. The archbishop mede no demur about granting them all their requests. " In all probability, horrever, the internal reform of the church was only of secondary importance in the minds of the clergy, for the case of Oldcastle had again been forced upon their notice. Among the condemned books two were found which contained doctrines of peculiar depravity. One is interesting on account of its place of pablication. It came trom Coventry, where $S$ winderby hed preached thirty years before, and which was still a notorious centre of Lollardy. The other work-a mere pamphlet-consistod of anbound sheets contsining several short tracts. It had boen found in the hands of an illaminator of Paternoster Row. The men, on being arrested, declared thet the book not his bat belonged to Bir John Oldosatle.

Oldcantle's name had now been twice brought before convocation, each time in bed company. The suspected priest bad given the authorities the slip, bat the obnoxions book placed what soemed incontestable evidence in their hande. They determined to strike at once. On 6 Jane, the very dey on which the Lollard artioles hed been formally condemned, some of the members of convocation went to the king at his manor of Kennington and read to him some of the most extreme concluaions of the book said to belong to Oldcastle. Sir John himself was present at the interview, and listened to the recital of the articles. The king was greatly shooked at the opinions put forward; they were, he esid, the worst he had ever heard. He then asked Oldcastle what he thought of the condemnation of the rork. Sir John unexpectedly replied that he considered the action of convocation quite right and proper. On being asked, very natarally, why he then possessed the book, he aaid that he never used it, and had not read more than two pages of it. ${ }^{74}$ Soon afterwards the lower clergy, having made a careful inquiry into the facts of the drew up a formidable indictiment against Oldcastle, and requested the archbishop and his suffragans to summon him before them to answer their accusations. But the prelates were in farour of proceeding with cantion, and thought it advisable to consult the king before again attacking untm de praecarissimis ex magnis domestices suis. So Arundel, the bishops, and 
a large number of clergy made another visit to Kennington, where Henry was stall residing, and 'tool connsel with him upon the matter.' They accused Oldcastle of being a notorions favoures of error and heresy; of holding, asserting, and defending erroneous and heretical conclusions in many dioceses of receiving, sheltering, and protecting unlicensed preachers; of sending them out to presch, attending their 'shamefal meetings,' and oppressing any who resisted them with threats and fears and the porrer of the sword; of declaring that no prelate might lawfally make constitutions for the regulation of preaching; and, finally, of holding heterodor views concerning the eacrament, penance, pilgrimages, Image-workhip, and the power of the keyв.

The king thanked them for the information; but he ras not the man to abandon a taithful servant without making an attempt to turn him from error. After reminding Arundel of the close friendship existing between Oldcastle and himself, and of the respect due to one of knightly rank, he asked the archbishop to delay further action till he had done what he could to turn Oldcastie from the error of his rays. If his attempts should come to nought, he promised to hand the heretic over to the charcl and to lend whatever aid the aecular arm could afford. The clergr grambled ; bat nothing was to be done but to accede to the king's raquest, and they had to go arvay and dissolve convocation with the knowledge that Oldeastle was still at large and, to all appearance, as prosperous as ever. ${ }^{\prime \prime}$ But through the whole affair, which must heve been most disagreeable to him, Henry acted straightforwardly. He did his best to sare his friend, but at the onme time he felt bound to do his duty by the charch. During the next two months he left no stone unturned in order to lead Oldcastle back to the 'fold of Christ.' "I But persuasion proved quite useless. According to the protestant writers of the sixteenth centary Old. castle thenked the king for his efforts, and declered himself anrious to remain a faithful servant of the crorn, but 'the pope and his alergy he would not obey.' 77 No open breach had taken place by the middle of Jaly; for on the 20th of that month Henry andertook by letters patent to pey by Alichaelmes 1414 tour hundred marks which were orring to Oldeastle and othera.n About a month later, however, while Henry was at Windsor, matters came to a

n Wilkins, iil. 209.

"Ibid.; Face. Zis. p. 400 ; Elmhem, Lib. Letr. p. 90 ; Gest. Bent. I. p. 2 , Cupgrave, $D$ illeutr Honr. p. 118 ; Redmegne, p. 16.

$\pi$ Redmayno, p. 16 ; Belo, pp. 21, 98.

- Poed. ix 11. The foor hundred merks were pert of the prioe of a olenp wid to have belonged to Slr Lowle Chtiford, who was long a expporter of Lolberdy. Hanry had

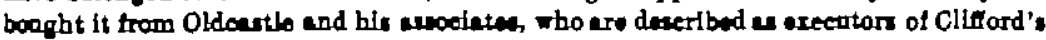

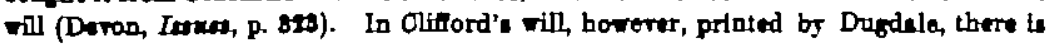
no meothon of ther of Obdeantlo or eny of tho othars (Baronage of England. i. 211) 
orisis. The king, exasperated by what he considered Oldcastle's obstinecy, broke out into fierce invectives against him-prasfathm dominum Iohannem super pertanacia sua acnter incropabat and Bir John, plenus diabolo, refusing to sabmit to this attack, went off without leave and shat himself up in Cooling Castle. The king promptly wrote to the archbighop, who was then near Chichester, ocoupied in colennius Assumptronu beatas Virginis. In his leiter Henry pat the whole case of Oldcastle in the hands of the ecclesisotical anthorities. ${ }^{79}$

Eventa now followed one another repidly. Henry eent writs to all the aheriffs, ordering them to provide for the arrest of unlicensed preachers and their aiders and abettors, and to seo that the constitations of 1409 were in no way infringed..$^{\text {so }}$ The church too lost no time in getting to work. Before long the archbishop's summoner appeared before Cooling Castle. But bere Oldcastle kept the gates shat. Now Arundel, anxious apparently to maintain the dignity of the servents of the church, had ordered that his messenger should on no account enter without leave, and that, through the mediation of a cortain John Batler, usher of the king's chamber, Oldcatle should be celled upon either to admit the summoner or to come outaide and receive the citation there. Oldcastle, as might have been expected, refused; and the summoner had to retarn to his master without acoomplishing any part of his errand. ${ }^{\text {s1 }}$ The archbishop at once ordered letters citatory to be pablicly affired to the doors of Rochester Cathedral. Oldcastle was summoned to appear at Leede Castle, near Maidetone, on Mondey, 11 Sept." Of course when the 11th arrived Sir Jobn failed to attand. It was reported to the arobbiahop that be pas fortifying himself at Cooling. Arundel promptly pronounced him contrmacions and excommuniarted him. On the same dey he cited him for 88 Bept., to set forth reasonable cease, if he hed any, why he should not be dealt with as a public heretic, schismatio, and enemy of the catholic churah."

What happened then is far from olear. The offlcial report proceds at once to 28 Bept., and states that on that date Sir John was brought by the keeper of the Tower before the archbiahop in the ohspter house of 8t. Paul's ; bat no erplenation is given as to how Oldeastle came to be in the hends of his conductor, or, indeed, how

Wrillins, Hil. 868 .

- Fand Ir. 46.

4 Fanc sis, p. 405 . Bele (p. $28 \mathrm{t}$ ) eyt thet when the wmmoner found Cooling

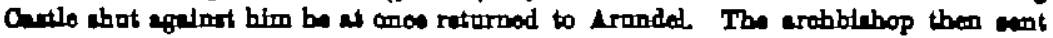





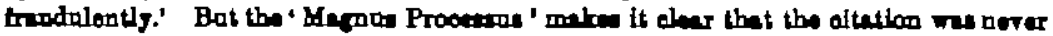
norred at all

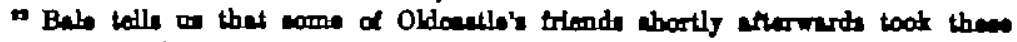
letters down; then now on ware pat ap on 8 Bept, thay wero ateo " rent down and uttinty confonme'

- Fana Ple p. 48.

voL. Ix-MO. Wx.

G $\mathrm{G}$ 
he got to London at all. In the reference to the citation for 28 Bept. nothing is said sbont London : as far a pe can judge Leeds was still intended to be the place of trial. No order for Oldcastle's errest eppeare in the close roll for the year. The archbishop himself has nothing to asy about it. There is no hint as to any resistance. From the 'Magnus Processens' it would appeser as if Oldcastle, who had gone awey from the hing without leare and twice refused to socept citation, either gave himself up or else tamely submitted to the first royal officer who came to demand his person.

It is possible, however, that Bale, of mall value for the history of Oldoastle as a general rale, may furnish something like a true account of what happened. He eays that, after his ercommanication at Leds, Oldcestle, ' beholding the onpeseable fory of antichrist thas kindled against him, perceiving himself also compessed on every aide with deadly dangera,' wrote ont a confession of his faith, containing a reply to the ohief counts in the accusetion againet him, and took it to the king. This confeesion, says Bale, opened with the Apostles' Creed; then ceme a more detailed expoeition of the writer's views on the Trinity and the Incarnation. Proceding further, Oldcastle declares Chriet to be the only head of the charch. The charch on earth is divided into three clase priesta, knighte, and commone. The functions of ench of these ections are then defined. An apparently orthodor statement of the doctrine of the eacrament followe. Finally, he declares bis belief that God arks no more of man than that he ahall obey his law. Should any prelate require any other kind of obedience, he contemneth Christ, and so becometh an open antiohrist.' After the confesion comes a strong appeal to the king that the whole document may be examined by the most godly and learned men of the realm, who should decide upon its orthodory. Oldenstle, Bale goes on to say, arrived at court; bat the king refused to receive his confession, ordaring him to deliver it to the ecclesiestice who were to judge him. 'Then desired he in the king's presenos that an handred knighte and esquires might be suffered to come in upon his purgation, which (he knew) wonld clear him of all heresieg.' He also offered to enbmit his faith to trial by bettle with any men living, the king and the lords of his council alone excepted, and declared himself prepared to acoept any sentence founded on "the laws of God.' The king thereupon received him 'in his own privy chamber,' rhere Oldcestle announced that he had appealed to the pope, and showed a copy of his appeal to Henry. The king was mach displesed : Oldcartle, he eaid, should not parsue his appeal ; whether he wished it or not, the archbishop should decide his case. The knight was thereupon arrested and committed to the Tower." This acoount reste eolely on Bale's authority, though he says he 
draws his facts from the retus exemplar Londinersism, a docament of which we have unfortanately no trace except in the Brefe Chronycle. If this vetus exemplar was a contemporary document there may be something in the above atory ; and in any case it is hard to discredit entirely the statement thet Oldeastle did visit the king."

Gregory in bis London Chroniole seye that Oldcastle ' was a restyde at Wynsore, and sende to the Toure of Lrondon,' $*$ and we know from the close rolls that the king was at Windsor on Monday, 18 Sept. This atory is ansupported; but the compiler of the early part of the chronicle would, as a Londoner, have had better opportanities than most of hearing the truth about prisonerg in the Tower : nor would this be the only time that he hit upon the truth when every one elee went wrong; for in gives a true statement of the time of Gloucester's death in

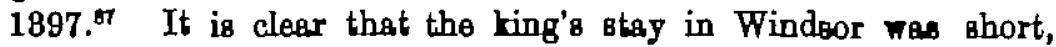
and it may have oped its speedy termination to his desire to take Oldcastle to London and see him safely into the Torer. This supposition mould explain the abeence from the rolls of any writs ordering his arrest or directing Bir Robert Morley, the keoper of the Tover, to receive him." Possibly Henry was still anxions to deal gently with his old friend, and refrained from treating him as an ordinary prisoner. The necesestry proceedinge would, therefore, be carried out quietly, and this might explain the almost manimous silence of the chroniclern. Such a conjecture seems to give the most reasonable explanation of a diffecalt problem."

On 28 Bept., as mentioned above, Bir Robert Morley brought Oldasetle before Arundel, who was at 8t. Panl's together with the bishops of London and Winchester. The archbishop at once

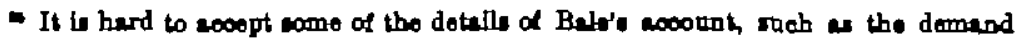
for pargetion by the Inight and equires $\alpha$ the eppeel to the pope. But it in

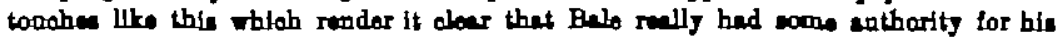
otatoments; ho would nover bare thonght of inventing a demend for a purgation of this wort, and ho wes the lart men in the world to tall wil that ble haro wished to

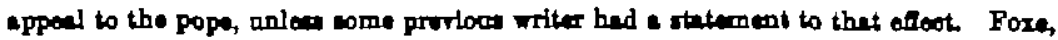

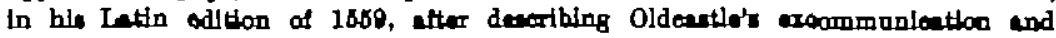
contloned dieregard for the arohbinhop, adden 'Regf tendem, mien ad cum proprio

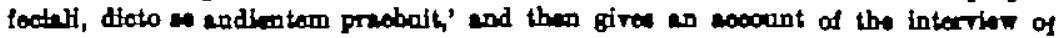

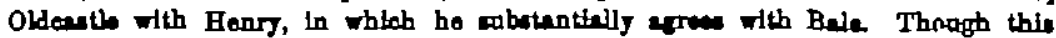
edition of Foro's work gire quite a different eovonnt of Oldoenth trom thet strbequently printed in Bnglteh, it is ungalo to regard bim en an ladepandent authority, as bo math here known tho Brofo Ohromplo well in 1669, thoogth he followed it with

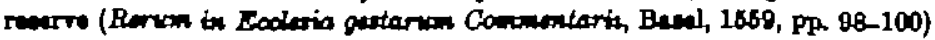

W Gregury's Chromiche, p. 107.

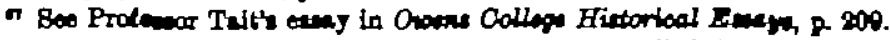

- Of courno writs mej havo ben ineded and not caralled, bot ordern for the srrwh and warnents to the kemper of the Towar for the commlttel, of prominent perrons serm as a rate to herv been entered in the petent or olow rolle.

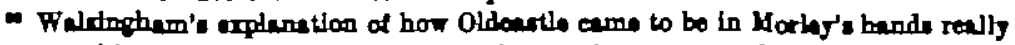

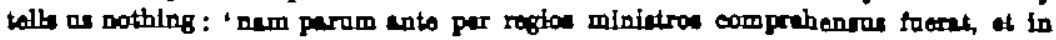
Turd oleuran.' 
proceded with the prisoner's exnmination. ${ }^{* 0}$ Throughout the whole trial he treated him very rell. He began by a formal recitation of the events leading ap to Oldcastle's excommunication, and concluded these preliminaries by offering to absolve him from the ben of the church. Oldcastle, somerhat ungraciously, took no noticeof this offer, but at once annonnced that he was prepared to declare his taith. Permisaion having been obtained, he drew from his cloak an indenture, read its contents, and hended one copy of this confession to the archbishop, keeping the other himeelf. The document, which was written in Englieh, lays down Oldcastle's views on the sacrament of the altar, penance, images, and pilgrimage; but, as is usual in Lrollard confessions of belief, the langarge is vague, and the main questions at issue are eluded. On the subject of pilgrimagee, indeed, Sir John statce explicitly that 'he that knoweth not, nor will not know nor keep the commendments of God in his living here, albeit he go on pilgrimage to all the world, and he die so, he ahall be damned." According to Bale Oldcastle prefaced his declaration with a protest against Arundel'B statements, presumably in the citations, that his views were contrary to the determinations of the church ;" but there is no notice of this in the official 'Processus.'

Arundel was a man of considerable experience in the examination of heretice. He knew that the points of view of the charch and the Lollards pere вo far asunder that no good could arise from argument. Aftar consolting with his asseseors, therefore, he went straight to the point. Bir John's confession, he said, was on the whole sound, but a fuller reply would have to be given concerning the sacrament of the eltar and penance: in the former case, did the material bread remain after consecration or not; in the latter, ras confession to a priest necesary? Oldcastle at first refused to make any further statement, and was warned by the primate that a persistence in this course might lead to his being forthwith declared a heretic. The threet, however, produced no effect. Arandel, who was clearly anrious to give Sir John every chance of asving himself, then explained to him the determination of the charch on the subjects in question, according to Baints Augustine, Jerome, $\Delta$ mbrose, and others of the fathers. Oldcastle replied 'that he was willing enough to believe and observe phatever holy ehorch had determined, and whatever God rished him to believe and observe; but that our lord the pope, the cardinals, arch. bishops, bishops, and other prelates of the church had the power of determining such things he was unwilling at that time in any wise to effrm." " $\Delta$ fter the closing words of this remark Arundel might have spared himself further trouble. Nevertheless he told

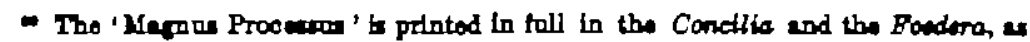
will at the Basdowli $Z$ inciationim.

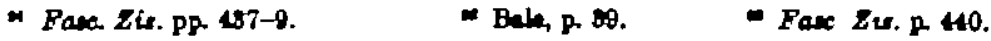


the prisoner that the anthorised doctrines on the chief mattern at isene should be written out for him, and translated into English, on account of Oldcastle's lack of learning (pro letiori intellectu siredem)." The accued would have the Sunday for consideration and on the Monday he was to make his reply. With this the session terminated, and Morley led his charge back to the Torrer."

On Monday, 25 Sept., the conrt was traneferred to the Blackfriars-8pparently a farourite place for the trial of heretice. The primate, evidently realising the importance of the occasion, had gathered together an imposing array of ecclesiastics. The bishop of Bangor had joined his brethren of London and Wincheater. The archbighop'в official had been summoned, as his legal adviser ; and four doctors of law were also present. Orford was represented by two doctors of divinity, and the friars by a prominent member of each of the four orders. A multitude of clergy and people appear to have been epactatore of the proceedinga. All the dignitaries and notaries having been sworn to give faithful counsel and earvice," Morley again brought Oldeastle before his judges." $\Delta$ s on the preceding Batarday the primate began by a recital of what hed been done from the beginning of the case, and afsin closed with an offer of absolution. Oldcestle replied that he would soek absolution from none but God." Bale makes Oldcastle go down on his knees and crave the forgiveness of God for youthful wickedneso-pride, wrath, gluttony, covetongness, lechery. Hir version is, however, quite unsupported by the official record; nor to it on the tace of it likely that Oldcatle would make such admissione just at that time: they would leave too good an open. ing for the churchmen to make reflexions as to the class from which Lollardy drew its eupporters. The eame writer's account proceeds with a description of a lengthy debate on the subject of the eucharist, leading to a hested argument on the authority of the church, interspersed with varions irrelevant diatribes of Oldcastle againet the eristing state and manners of the clergy. Bir John, it would appeser, grew more and more violent, and at lest simply abuive. His invective was much better than his

- If Bir Jahn hed been able to anderitend Latin, Arondel would herdly have been at the peins of haring the tramaletion mado for hil beneft.

- Face. 8ir. p. 140 II.

- Grugory, p. 107; Beto, p. 17 ; Rat. Porl. ir. 109 . The Oxford heretien hed been tred at the Blectetriers in 1889, and tho trit exemlnation of Bedby hed been hald at the seron pleocen

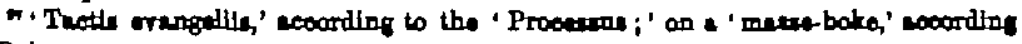
to Belo.

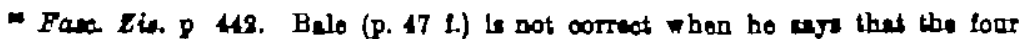
thane present ware the heads of therr rapootive orders in Englend. Filden did not beome protodel of the Curmalites till the following yas.

- Fane Er. p. 44. 
dialectic, though neither gide displayed any very cogent reasoning. The whole debate was fatile, and srundel showed good sense in patting an end to it and demanding an explicit answer to the articles submitted to the accused on the previous day..$^{100}$ While it is hard to believe that Bale's account of the session down to this point is all fiction, it is perhaps safer to regard the official report as presenting, in a condensed form, the actual course of erents.

Arundel's 'Processas' has nothing of this preliminary discussion; after mentioning Oldcastle's refusal to receive absolution from the archbishop, it goes on at once to his replies to the 'determinations of the church.' This last part of the trial lasted only a short time. On the encharist Oldcastle professed a theory much like that which Lather afterwards held : the crucial point in it was that after consecration bread did actually remain. With reference to penanoe he aserted that confession to a priest, though sometimes erpedient, was not necessary to salvation. The cross, he held, was not to be adored; he would be willing to keep it clean and in a eafe place, but that was all the honour he would pry it. As to the power of the keys, Bir John at once openly declared that the pope was the head of entichrist, the archbishope and bishops were his members, and the triars his tail : the pope and prelates were not to be obeyed, except in as far as they were imitators of Christ and Peter in life, manners, and conversation; and he alone ras the trae successor of Peter who ras good in life and pure in manners. Then, torning to the spectators, he warned them against his judges, saying that they were the seducers of the people and would lead them to hell. ${ }^{101}$

There way no nead to prolong matters further. The chorch had given Oldcastle a fair hearing; he had felt himself anable to make ase of it for his safety, and had ueed language which no prelate could possibly suffer to go unpanished. So the archbishop, 'with mournful countenence,' once agrin exhorted him to reconsider his views and return to the anity of the charch; bat the prieoner remained steadfast and refused in any way to elter his former declarations. Seeing that he could not suocoed in turning him from his resolution, Arundel, 'with bitterness of heart,' procoeded to pronounce sentence. Oldcastle was ercommunicated and handed over to the secular arm. ${ }^{102}$ All favourers, receivers, and defenders of the condemned man rere likeribe included in the sentence; and, that such might not plead ignorance of what had happened, the primate in a letter of 10 Oct. ordered his saffragans

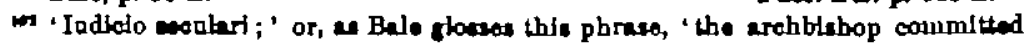
Obdoaste ' to the coculer fariediotion, power, and judgment, to do him thereapon to denth.' 
to cause the official 'Processus' to be reed before the people in every chareh throughout the provinee of Centerbury.

Bat Oldcartle, though formally condemned, was to receive yet another piece of farour. Instead of being led out to execution he was granted forty deye' respite in the Tower, ${ }^{103}$ in the hope thet he might still turn from the path of heresy. The king was probably responsible for thin act of grace. ${ }^{104}$ Walsingham, indeed, sayt thet Arandel, on reporting the result of the trial, besought Henry to defer giving effect to the entence. Bat this version finds no independent support. ${ }^{14}$ Arondel had just condemned Oldcestle as incorrigible; to beg for a reprieve would thas have been tantamount to an admiasion that he had gone too far. On the other hand Henry, reluctant, no doubt, to lose s eervant of proved capacity, could give Oldcastle another chance by eimply putting off the issue of the writ of execution, without openly shoring favour to 2 heretic. ${ }^{10}$ Doubtless Henry consulted Arandel before deciding on his course of leniency; but the primate mast have felt too much indebted to the king for his pert in the proceodings againgt Oldcastle to raise eny objection to his wishes.

W. T. WAUGH.

(To be conimscad.)

NOTE.

The abjoration of Oldeastle, found only in the Fasoiouli Zuario$\mathrm{rum}^{107}$ is unsupportod by any contemporary anthority. It is conequently no ronder thet protestant writers have considered it apurioas. Bele unhesitetingly prononnes it a forgery, and hes expressed bis opinion in a merginal note in the manusoript of the Fasoiouli be This riew is elaboreted in his Brefe Chronycle. Oldaestle, bo mys, during his impriwonment in the Torrer menaged to keep up correspondenoe with his friends onteide. From them he learned thet damaging reports as to his ateadintiness were

meato Hentr. V, p. 8; Walsinghem, 11. 290 ; Blmham, Lib. Motr. p. 97 ; Ceprreve, De illent. Hewr. p 118; Redmegne, p. 16. Bele, it may be noted, morely mentions thet Oldeantlo was kopt in the Tower athar his candamnation, and carafully rotrains troen eny hint eboat an eat of terour.

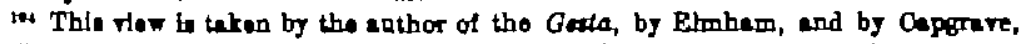

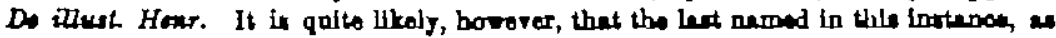
in many otbars, derived bis Informetton trom Blmharn.

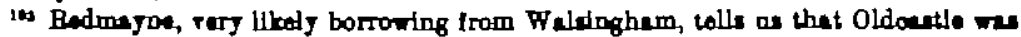
committed to the Towes 'lasen Arohiopisoopl.'

mo granting of a reppite wa in livelf an ect of terour. In cases of heresy

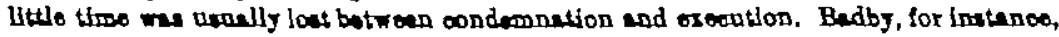
hed been borat a for hoors after he wee sentenoed In Bewtre's ane the with of areantion hed been held orer, bat only for tour dese.

in P. 114 II.

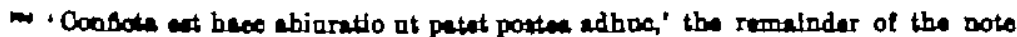
boing illeglble (p. 114, n. 1). [The tollowing words in the menuecript, $1.97 \mathrm{~b}$, which


apod multos,' writton and partly rowritten by Bato orer an oracuro-ED. E. H. B.] 
being spread sbroed by the bishopu' servanta. To connteract the effect of thew bo arranged thet a 'littile bill,' contelning a deniel that he hed in eny way eltered bis opinions, thould be poated up in verious perte of London. Atter this the olergy fell into very bed adour with the lesity in general, who nympathied with Bir John; end to rentore their own oredit, and at the ame time to demege Oldcastle's repatation, they forged en abjuration

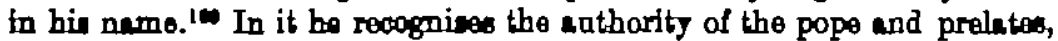
and their right to esteblisb and enfores ecolesiastical constitutions, renounces all bla herotical beliafs, decleres bimelf ready to andergo eny penance which Arundel may thenl fit to impowe on him, and promines to inform the clargo of any hetarodor persons he may hesr of.

Oldonstle ean never have made sach s reantation, for if he hed done wo he would heve been wet at liberty, whereas all anthoritied efree that he ped from the Tower by stealth. It is just poesible that he may in a moment of reatmea have signed the document, and aftarwards withdram from it, though the absence of any reference to his sotion in eny reoord of the time makes the expposition bighly improbable. But, grented that the abjuration never received Oldeastle's dignature, it it not necessary to accuse the pralntes of deliberate forgery. It is clear that no officiel story of an ebjuration was earrent. No one conld conceivably here hoped to deseredit Oldeastle by forging a document snd then concealing it. More probably the 'confeseion' is a mere draft, drawn up toward the olose of Oldcestle's eremination, or while he pas in the Torrer, ${ }^{110}$ and intended to be onbmitted to him for his cigrature, in ase he should show any sign of relenting. After the prisoner's ecape wah a doeument would, of conrse, be useless; but Walden, it rould eppen, wmehor got posescion of it, end pleced it among hil papers. Possibly, indoed, he had composed it bumself, with the idee that It might prove asefol ; we know thet he pas present at Oldestle's second examization," aroso-questioning to which the socused was subjected." 1 ' On Walden's denth the peper was found, and inearted in the volume which has come down to as. is

100 Heln, P. $81 \mathrm{II}$.

1to The wuthor of the Geata ba en Interesting steternent in tht connexton: "Intre

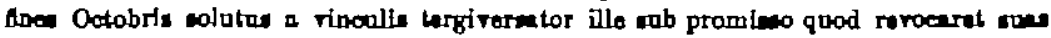

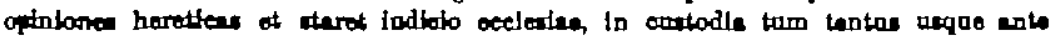

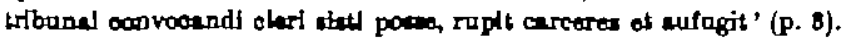

111 Fane Zu. p. 148.

in Balo, pp. $88-60$.

"s Be Fana Eir. fntr. pp. Irxil, Inxili. 